\title{
Political Violence and Excess Liquidity in Egypt*
}

\author{
David Fielding* and Anja Shortland ${ }^{\S}$
}

\begin{abstract}
In this paper we estimate a time-series model of excess liquidity in the Egyptian banking sector. While financial liberalization and financial stability are found to have reduced excess liquidity, these effects have been offset by an increase in the number of violent political incidents arising from conflict between radical Islamic groups and the Egyptian state. The link between political events and financial outcomes provides a rationale for economic policy interventions by the international community in response to increases in political instability.
\end{abstract}

Word count: 5663 including endnotes

JEL Classification: G21, O16

Keywords: Egypt; Excess Liquidity; Political Violence; Radical Islamism

\footnotetext{
* We would like to thank Mohammed Hafez for the data-set on political violence in Egypt and seminar participants at the University of Leicester, the University of Sheffield, and the EEA meeting in Stockholm as well as two anonymous referees for their helpful comments. All remaining errors are our own.

* University of Leicester and Centre for the Study of African Economies, University of Oxford.

$\S$ University of Leicester. Address for correspondence: Department of Economics, University of Leicester, Leicester LE1 7RH, England. Telephone +44-116-252-5385. E-mail A.Shortland@le.ac.uk.
} 


\section{Introduction}

The 1990s have seen a renewed interest among economists in the possible connections between a country's economic performance and the social and political conditions that prevail there. Research based on cross-country studies indicates that there are strong correlations between countries' long run growth rates and their political characteristics. These characteristics include such factors as the degree of democracy, the degree to which civil and political rights are respected and the degree of political instability and violence. Alesina and Perotti (1994) survey many of the papers outlining these ideas. While different papers find different socio-political indicators to be significant in explaining variations in growth rates across countries, there is a consensus that a substantial fraction of the variation is to be explained by the quality of a country's political system. There is also a closely related literature examining cross-country variations in investment performance. A paper by Alesina and Perotti (1993) explains such variations by using a "socio-political instability index". The important factors in the index are indicators of the absence of democracy and the incidence of political violence. Kormendi and Meguire (1985) and de Haan and Siermann (1996) discover a negative cross-country correlation between the investmentGDP ratio and indices of political freedom. Finally, recent research indicates that capital flows and financial market development in LDCs (and particularly in Africa) are sensitive to indicators of political instability (see for example Fedderke and Klitgaard, 1998; Fedderke, 2000; Fedderke and Liu, 2002). However, there is little evidence about the mechanisms through which political instability impacts on investment.

In this paper we use a new Egyptian dataset on Islamist violence to explore one possible route by which instability affects the real economy: by generating excess liquidity in the banking sector. However, the interest in the effect of Islamist violence on the Egyptian economy extends beyond the parochial. Firstly, several countries are experiencing religiously motivated terrorism (e.g. Sudan and Algeria), but it is impossible to study the economic consequences because of unreliable macroeconomic data. Secondly it appears that Islamist terrorism is on the rise in other countries such as Indonesia, Pakistan, Saudi Arabia and Tunisia. Therefore Egypt, which has both a history of religious conflict and a reliable statistical service represents an interesting case study of the effect of Islamist violence on economic outcomes. This paper is part of a wider research programme on the effects of political instability on macroeconomic outcomes, which also includes studies on Israel (see Fielding 2003, and Fielding and Shortland, 2002). 
Early in the 1990s the Egyptian government instituted a reform program - the Economic Reform and Structural Adjustment Program (ERSAP) - that was largely successful by many conventional criteria. Domestic capital markets were successfully liberalized, and financially repressive controls on interest rates were removed. One aspect of the liberalization was to reduce banks' reserve requirements on Egyptian pound deposits. ${ }^{i}$ The required liquidity ratio (of reserve assets to deposits) was reduced from 30 per cent to 15 per cent in 1990 . This change was motivated by orthodox macroeconomic theory: reducing seigniorage taxes on the banking system will promote financial development and growth in the real economy.

The aggregate liquidity ratio of commercial banks did indeed fall after the reform. But it is striking that all through the 1980s and 1990s, actual ratios were much higher than the minimum required by Egyptian law. Figure 1 illustrates the aggregate ratio: it suggests that the minimum reserve requirement - always high by the standards of industrialized economies - was never a binding constraint. In many years banks lent less than half of the money deposited with them. Identifying the reasons for such excess liquidity is essential if we are to understand the factors that inhibit financial development in countries like Egypt.

One hypothesis that deserves attention is that bank lending in Egypt has been limited not only by economic instability but also by political instability. Just as uncertainty in economic conditions might lead banks to behave more cautiously, so also might uncertainty in political conditions, for reasons that we elaborate below. The period of economic reform coincided with an increase in the intensity of violent protest by radical Islamist groups excluded from the Egyptian polity. In this paper we will investigate the possibility that this violence offset some of the improvements in the financial system engendered by the ERSAP. The next section explores the nature of the political violence, and its potential economic consequences.

\section{Radical Islamism, Violence and the Egyptian Banking System}

Egypt's most recent economic reform has coincided with substantial fluctuations in the level of political violence in the country. The aim of the next section will be to estimate the relative magnitude of the political and economic determinants of bank liquidity. In this section we review the underlying causes of political violence, and explain why they might lead to excess liquidity.

Islamist movements were banned from Egyptian politics in 1954 and went underground in response to government repression. During the 1970 s, however, there was a general Islamist revival, spread through 
mosques, youth clubs and cultural and welfare organisations. There were two main Islamist movements: alIkhwan al-Muslimun (the Muslim brotherhood), which was non-violent and Al-Jama'a al Islamiya, which had no political programme but a preference for direct action. During the 1970s the low-level Islamist violence was mainly directed against the Christian minority, the Copts.

Political violence increased in the 1980s as Islamists opposed the government's rapprochement with Israel and its pro-Western stance and was increasingly directed against the state. The radical wing of the Ikhwan movement gained prominence in the otherwise non-violent movement and Upper Egypt's Jama'a movement joined forces with the radical al-Jihad organisation. The violence culminated in the assassination of President Sadat in October 1981 and the insurrection of radical Islamists in Asyut. The state's draconian response to these events succeeded in lowering the number of violent incidents from 1982 to 1985.

From 1984 the Ikhwan movement became a player in Egyptian politics as it was tolerated as a religious group and cooperated with the Wafd party to gain parliamentary representation. Ikhwan therefore became committed to pluralism, gradualism and non-violence. Violent acts were mainly committed by Jama'a in Upper Egypt, which desired to impose Sharia laws. Attacks were therefore mostly targeted at musical festivals, beer deliveries, cinemas and individuals engaged in "vice". The secular government responded to these incidents with mass arrests and the storming of Jama'a mosques. The violent repression turned public opinion against the government.

From late $1989 \mathrm{Jama}$ 'a started to target prominent officials for assassinations. In December 1989 an unsuccessful attempt was made to assassinate the interior minister Zaki Baldr and in 1990 the former speaker of parliament Rafat al-Mahjoub was assassinated. From 1992 a vicious circle of incidents of violence and counter-violence began. Through 1992 and 1993 there were almost daily incidents of violence. Jama'a formed an official armed wing using high-tech explosives and military intelligence, which attacked policemen, security forces and prominent government officials. There were also attacks on banks and foreign exchange bureaus. The government reacted by suppressing the Ikhwan movement politically and arrested those Ikhwan members most likely to stand for the 1995 parliamentary election. In response the Islamists began a series of direct attacks on tourists and issued communiqués for Western tourists to stay away from Egypt. Examples of such attacks include those on Greek tourists outside their Cairo hotel in April 1996, German tourists beside Cairo Museum in September 1997, and tourists in Luxor in November 1997. 
In conclusion, therefore, the political stance of the Egyptian government towards Israel and its repression of Islamist fundamentalists meant that Islamist violence was increasingly directed against the state. Radical Islamist groups employed a variety of strategies, designed to harm the government directly through assassination attempts or indirectly through undermining tourism, which provided much of the government's revenues and hard currency income. Data presented in Fielding and Shortland (2002) indicate that this strategy was successful in the sense that increases in violence appear to be correlated with reductions in real output in the tourist industry, ceteris paribus.

This correlation with real economic activity means that banks' liquidity ratios are likely to vary with the level of violence. As the level of violence increases, the risk of loan default increases, motivating an increase in liquidity. The effect in Egypt may be magnified because banks are anxious to maintain depositors' confidence in the financial system, which was plagued by weak loan portfolios. Egypt does not have an official deposit insurance scheme, and capital-asset ratios in the 1980s were very low due to previous banking losses (Handy et al., 1998). In times of political turmoil, when depositors suspect that the rate on default on bank loans is going to be very high, higher liquidity ratios may be the only way of preventing banking runs. It is true that the government directly controlled a large proportion of the Egyptian commercial banking system through ownership of commercial banks and stakes in joint venture banks ${ }^{\text {ii }}$ and it is reasonable to assume that these banks were covered by an implicit state deposit guarantee. But the government's resources were affected by the fiscal cost of repressing Islamists and guarding state institutions and tourists sites against attacks and the loss of revenues through deterred tourism. Savers' perceptions of the government's willingness to compensate savers in the event of a public sector bank failure could therefore be undermined by an increase in violence. Runs on the public sector banks also had to be prevented through maintaining higher liquidity ratios.

Estimating the size of this excess liquidity effect depends crucially on measuring accurately changes in the level of violence. Data from Abul'ala (1998) and Hafez (2000) summarize the fluctuations in the level of violence in Egypt over the last 20 years. These data record the number of violent political incidents in Egypt associated with government-Islamist conflict each year, based on reported incidents in the Egyptian press. As Figure 2 shows, the number of incidents is highly variable, reflecting the changing trends described 
above. ${ }^{\text {iii }}$ These data will be incorporated into an econometric model that will allow us to estimate the impact of changes in violence on banks' behavior.

\section{The Model of the Reserve Asset Ratio}

\subsection{Theoretical background}

The theoretical model that underpins our empirical analysis of the aggregate reserve asset ratio in Egypt is outlined by Agénor et al. (2002), who draw on earlier work by Baltensperger (1980) and Prisman and Slovin (1986). In this model, reserves are necessary because banks face liquidity risk. The fraction of deposits that are backed by reserves will depend positively on the conditional variance of the private sector's demand for cash, which under plausible assumptions about the money demand function will be a linearly separable function of the conditional variance of the cash-deposit ratio and the conditional variance of the determinants of total money demand, in particular real output. ${ }^{\text {iv }}$ These conditional variances capture the magnitude of risk that there will be a large unanticipated increase in withdrawals that banks cannot meet. If the conditional variances change over time, then we ought to see corresponding changes in the reserve ratio, ceteris paribus. The reserve ratio will also depend positively on the opportunity cost of borrowing from the monetary authority when customers demand more cash than the bank has available (i.e. on the central bank discount rate), and on the minimum reserve requirement of the monetary authority. In addition, the regression equation for the reserve asset ratio in the Agénor et al. paper includes a term capturing real output relative to trend. The ratio might be pro-cyclical because banks need to build up reserves in anticipation of credit defaults in the next recession.

In the case of Egypt, measurement of the level of real output, the discount rate and the reserve requirement is straightforward. (The last of these is in effect a dummy variable, since in our sample period, 1983-96, the reserve requirement changed only once, at the end of 1990, as part of the ERSAP.) The measures of conditional variance are less straightforward as they depend on which variables are chosen to model the cash-deposit ratio $(C / D)$ and the level of output $(y)$. Nevertheless, a wide variety of regression specifications for these two variables - the most parsimonious of which are detailed in Table 1 - produce the same stylised result: that is, there are no significant changes in the conditional variances over the time period we are looking at. In other words, there is no autoregressive heteroskedasticity in either $\ln (C / D)$ or $\ln (y){ }^{v}$ 
The only source of heteroskedasticity is a correlation between the residual variance in the $\ln (y)$ equation and a dummy for the ERSAP reform at the end of 1990. Figure 3 illustrates the squared residuals from the Table 1 regression equations. Aside perhaps from a reduction in the conditional variance of income after the reform, the stochastic elements of $\ln (C / D)$ and $\ln (y)$ are homoskedastic. So, controlling for the reform, there ought to be no variation in the reserve asset ratio associated with changes in the conditional variance of asset demand. For this reason, there are no variance-based measures of economic risk in our regression equation for the reserve ratio in Table 2 below. This is not because we think that economic risk doesn't matter, but rather because variance-based measures of economic risk have remained constant over time.

However, such measures of conditional variance might not capture all of the risk facing banks in a country like Egypt, even after political factors have been taken into account. Bahaa Eldin and Mohieldin (1998) point out that commercial banks (especially those that are state-owned) are often under political pressure to lend to ailing companies, regardless of their creditworthiness. Roe (1998) notes that commercial banks' loan portfolios are typically characterised by limited diversification and high rates of non-performing loans, especially in the case of publicly owned commercial banks. The fraction of non-performing loans is variously estimated to be 30 per cent to 45 per cent cent of the total.

It is likely that the risk banks face from such loans rises with the magnitude of macroeconomic distortion in the Egyptian economy. Those companies with privileged access to commercial bank loans though the patronage of a particular government ministry are also likely to have privileged access to rationed foreign exchange. The larger the distortion in the foreign exchange market, the more likely it is that these companies will become insolvent once the market has been liberalized and the cost of foreign currency has increased to its market-clearing level. (Figure 4 indicates that the number of bankruptcies in Egypt did increase in the wake of the reform programme.) So we will allow the liquidity ratio of commercial banks to depend on the rate of depreciation of the black market exchange rate of the Egyptian pound against the US dollar. This variable is depicted in Figure 5, which shows that the foreign exchange market became increasingly distorted during the fixed exchange rate period 1985-1989. During the 1990-91 reforms the foreign currency market was liberalized, and the black market rate remained constant at a trivially small premium over the official rate. We conjecture that part of the impact of the economic reform on the liquidity 
ratio can be captured by changes in the black market exchange rate. (The other part, relating to the change in reserve requirements and the decrease in income volatility, will still be captured by the ERSAP dummy.)

\subsection{The econometric model}

On the basis of the preceding discussion, we will estimate a regression equation for the logarithm of the reserve assets ratio, $\ln (R)$, conditional on the following quarterly time-series:

1. REFORM: a dummy for the post-reform period (1991 onwards);

2. $\ln (y)$ : the logarithm of real GDP;

3. $\Delta \ln (b)$ : the rate of parallel exchange rate depreciation;

4. $r$ : the central bank discount rate;

5. $\ln (v)$ : the index of political violence.

Data are available for the period 1983-96. ${ }^{\mathrm{vi}}$ Augmented Dickey-Fuller tests for stationarity of the data (available on request) produce mixed results. $\Delta \ln (b)$ is clearly stationary. For the other variables, the null of difference stationarity cannot be rejected at the five per cent level, although the test statistic for $\ln (y)$ is very close to the five per cent critical value. For this reason we will estimate the regression equation using the approach advocated by Pesaran et al. (2001); this allows us to remain agnostic about the order of integration of the series. Our regression equation is of the form:

$$
\begin{aligned}
\Delta \ln (R)_{t}= & \beta_{0}+\phi \cdot t+\theta \cdot R E F O R M_{t}+\sum_{i=1}^{i=T R} \beta_{i} \cdot \Delta \ln (R)_{t-i}+\sum_{i=0}^{i=T s} \gamma_{i} \cdot \Delta \ln (y)_{t-i}+\sum_{i=0}^{i=T b} \delta_{i} \cdot \Delta \ln (b)_{t-i} \\
& +\sum_{i=0}^{i=T r} \zeta_{i} \cdot \Delta r_{t-i}+\sum_{i=0}^{i=T v} \eta_{i} \cdot \Delta \ln (v)_{t-i}+\beta^{*} \cdot \ln (R)_{t-1}+\gamma^{*} \cdot \ln (y)_{t-1}+\eta^{*} \cdot \ln (v)_{t-1}+\varepsilon_{t}
\end{aligned}
$$

where $\varepsilon_{t}$ is a regression residual and the lag order of each variable $z, T_{z}$, is chosen so as to minimize the Schwartz-Bayesian Information Criterion. ${ }^{\text {vii }}$ We take it that all of the differenced variables in the equation are definitely stationary, but allow for the possibility that the lags of $\ln (R)_{t}, \ln (y)_{t}$ and $\ln (v)_{t}$ appearing on the right hand side are I(1), so that the t-ratios on the starred coefficients might not have a standard tdistribution. ${ }^{\text {viii }}$ However, Pesaran et al. (2001) demonstrate that there is a range of critical values of the standard F-statistic for the joint significance of the starred coefficients corresponding to different assumptions about the order of integration of the three variables. Assuming that $\ln (y)_{t}$ and $\ln (v)_{t}$ are long-run forcing variables, the upper bound of this range (computed by Pesaran et al.) corresponds to the case where 
$\ln (R)_{t}, \ln (y)_{t}$ and $\ln (v)_{t}$ are all $\mathrm{I}(1)$. The lower bound to the case where they are all $\mathrm{I}(0)$ (in which case we can use the ordinary F-distribution). If our F-statistic is greater than the upper bound, then we can be confident that there is indeed a long-run (cointegrating) relationship between the three variables.

The regression equation is reported in Table 2 below. The coefficients on each of the explanatory variables are statistically significant and their signs are consistent with the theory discussed in Section 2 . The diagnostic statistics reported in Table 2 suggest that the regression is statistically robust. The reported F-test for the joint significance of the levels variables is greater than the upper bound of the five per cent critical value reported in Pesaran et al. (2001).

Rather than interpreting individual coefficients in the regression equation, we will refer to Figure 6 below. This figure depicts the response of $\ln (R)$ to a unit shock to each of the four explanatory variables: $\ln (y), \ln (v), r$ and $\ln (b)$; the response is charted over ten quarters, by which time the responses are very close to their respective asymptotes. The impulse responses chart the consequences of a permanent shock to the level of each variable, i.e., a temporary shock to the growth rates $\Delta \ln (y), \Delta \ln (v), \Delta r$ and $\Delta \ln (b)$. One measure of the impact of a "typical" shock to each variable is this impulse response scaled by the standard deviation of the growth rate of the variable. So Figure 6 also notes these standard deviations, which are labelled "s.d.".

Figure 6 shows that both shocks to the level of political violence and shocks to GDP have permanent effects on the reserve asset ratio. In the case of GDP, the impulse response profile is monotonic: a (positive) unit shock to output leads to a 72 per cent increase in the ratio on impact, rising to 166 per cent in the long run. Since the standard deviation of $\Delta \ln (y)$ is 0.025 , this means that a typical shock to output would eventually change the reserve asset ratio by 4.2 per cent in the absence of further shocks. In the case of the political violence index the adjustment path is not monotonic, but the effect of a (positive) unit shock is to increase the ratio by 15 per cent on impact, and by 13 per cent in the long run. ${ }^{\text {ix }}$ Since the standard deviation of $\Delta \ln (v)$ is 0.313 , this means that a typical shock to the level of violence would eventually change the reserve asset ratio by 4.1 per cent in the absence of further shocks. In other words, the long-run consequences of economic and political shocks are of approximately equal magnitude.

Permanent shocks to the level of the discount rate $(r)$ and the black market exchange rate $(b)$ both have a temporary impact on the level of the reserve asset ratio. The impact effects of standard deviation 
shocks to these two variables are of the same order of magnitude: a positive shock to $r$ raises the ratio by 4.8 per cent on impact; the corresponding figure for $\ln (b)$ is 2.5 per cent. These effects are roughly halved by the fourth quarter after the shock, and have virtually disappeared by the eighth quarter.

These findings are consistent with the theoretical model of the reserve assets ratio discussed above: the ratio is pro-cyclical, and responds positively to increases in the discount rate (although this response seems only to be temporary). Moreover, it also responds positively to the degree of macroeconomic instability, as captured by the rate of parallel market exchange rate depreciation. The removal of this source of instability in the 1990-91 ERSAP, along with the financial reforms proxied by our REFORM dummy, was one reason for the substantial reduction in the average reserve deposit ratio, as seen in Figure 1. The difference between the logarithm average level of the reserve asset ratio in the pre-reform period (1983-90) and that in the post-reform period (1991-96) is 48 per cent. Our regression results imply that of this, 23 per cent is due to the reform measures captured by the REFORM dummy, and 8 per cent is due to a lower rate of parallel market exchange rate depreciation. ${ }^{\mathrm{x}}$ However, the regression results also imply that the fall in the ratio would have been much greater, were it not for the increase in political violence. In fact, the reserve asset ratio in the post-reform period is estimated to be 35 per cent higher than it would have been if the level of violence had not increased. ${ }^{\mathrm{xi}}$ (A large part of the observed fall in the actual ratio is because interest rates have been falling post-reform, and that there is an underlying downward deterministic trend in $\ln (R)$, as seen in Table 2.)

The bottom line here is that the beneficial consequences of the improvements in the Egyptian financial system for excess liquidity were of the same order of magnitude as detrimental consequences of the increase in political violence. In the light of our regression results, it is not at all surprising that the current reserve asset ratio is around 60 per cent higher than the minimum required ratio. Figure 7 emphasises this fact by illustrating the difference between the equilibrium level of the reserve assets ratio, calculated from the long-run elasticities implicit in Table 2, and a corresponding hypothetical level that we could have expected in the absence of any violence. ${ }^{x i i}$ The estimated equilibrium level was around 25-30 per cent through the 1990s, and (as the figure shows) it would have been even higher in the absence of the 1991 reforms. But in the hypothetical non-violent scenario the ratio trends gradually downwards to below 15 per cent by the mid 1990s. The size of the violence effect is greater than that of the reform effect. 


\section{Conclusion}

In the early 1990s the Egyptian government undertook a substantial monetary reform program that included a liberalization of foreign currency and capital markets: the authorities removed financially repressive interest rate controls and eliminated the black market exchange rate premium. Although these reforms did lead to some improvements in the efficiency of the financial sector, large inefficiencies remain; one of the most prominent of these is the large degree of excess liquidity in the commercial banking sector. We have shown that one of the main reasons for the excess liquidity is the increase in the intensity of political conflict between the Egyptian state and radical Islamist groups.

These stylized facts lead to two conclusions. First, reform packages that concentrate solely on financial and economic factors are unlikely to be effective in promoting confidence in the local economy if they do not also deal with the causes of political conflict in the country concerned (in this case Egypt). Second, successful political reform will lead to a reduction in the fraction of commercial banks' assets made up of reserve money. This will generate extra inflationary pressure. While there are likely to be substantial long-term benefits from an increase in bank lending to the private sector, there may be higher inflation in the short run. This may place extra political pressure on the government during an attempt to introduce political reforms. To the extent that the international community has an interest in seeing a reduction in radical Islamist violence, it should indicate that its financial institutions stand ready to support political as well as economic reform programs.

\section{References}

T. Abul 'ala (1998) Aliyat al-Taghier al-Dimuqrati fi al-Watan al- `Arabi, Beirut: Markaz al-Disarat al-Wihda al-`Arabiya P-R.Agénor, Aizenman, J. and Hoffmaister, A. (2002) "The credit crunch in East Asia: what can bank excess liquid assets tell us", mimeo, World Bank, Washington, DC

A. Alesina and Perotti, R. (1993) "Income Distribution, Political Instability and Investment", NBER Working Paper 4486

A. Alesina and Perotti, R. (1994) "The Political Economy of Growth", World Bank Economic Review, Vol.8, pp. 351-71

Z. Bahaa Eldin and Mohieldin, M. (1998) "On prudential regulation in Egypt", in El-Erian, M. and Mohieldin, M. Financial Development in Emerging Markets: The Egyptian Experience, Cairo: Egyptian Center for Economic Studies

E. Baltensperger, (1980) "Alternative approaches to the theory of the banking firm", Journal of Monetary Economics, Vol.6, pp. 1-37

J. de Haan and Siermann, C. (1996) "Political Instability, Freedom, and Economic Growth", Economic Development and Cultural Change, Vol. 4, pp. 339-50

Fedderke, J. and Klitgaard, R. (1998) "Economic growth and social indicators: an exploratory analysis", Economic Development and Cultural Change, Vol.46, pp. 455-90

Fedderke, J. and Liu, W. (2002) "Modelling the determinants of capital flows and capital flight: with an application to South African data for 1960-95", Economic Modelling Vol.19, pp. 419-44

Fedderke, J. (2000) "Investment in fixed capital stock: the South African manufacturing industry 1970-97", ERSA Working Paper 16, University of the Witwatersrand, http://www.wits.ac.za/economics/ersa 
D. Fielding (2003) "Modeling Political Instability and Economic Performance Israeli Investment during the Initfada", Economica, Vol.70, pp. 159-86

D. Fielding and Shortland, A. (2002) "How does political violence affect currency substitution? Evidence from Egypt", mimeo, University of Leicester, UK

M. Hafez (2000) Islamism Between Accommodation and Insurgency: a Political Process Explanation of Islamist Strategies in Algeria and Egypt, Ph.D. dissertation, London School of Economics

H. Handy, Allum, P., Bisat, A., Daniel, J., Kahn, R., Lane, C., Mecagni, M., Mongardini, J. and Subramanian, A. (1998)

"Egypt: Beyond stabilisation, towards a dynamic market economy", IMF Occasional Paper 163

B. Hansen (1992) "Testing for parameter instability in linear models", Journal of Policy Modeling, Vol.14, pp. 517-33

R. Kormendi and Meguire, P. (1985) "Macroeconomic Determinants of Growth: Cross-country Evidence", Journal of Monetary Economics, Vol.16, pp. 141-63

J. Lisman and Sandee, J. (1964) "Derivation of quarterly figures from annual data", Journal of the Royal Statistical Society (Series C), Vol.13, pp. 87-90

H. Pesaran, Shin, Y. and Smith, R. (2001) "Bounds testing approaches to the analysis of level relationships", Journal of Applied Econometrics, Vol.16, pp. 289-326

E. Prisman and Slovin, M. (1986) "General model of the banking firm under conditions of monopoly, uncertainty and recourse", Journal of Monetary Economics, Vol.17, pp. 293-304

A. Roe (1998) "The Egyptian banking system: liberalization, competition and privatization", in El-Erian, M. and Mohieldin, M. Financial Development in Emerging Markets: The Egyptian Experience, Cairo: Egyptian Center for Economic Studies

\section{Notes}

${ }^{\mathrm{i}}$ In this paper we will focus on the evolution of reserves and deposits in local currency. Fielding and Shortland (2002)

deals with the issue of currency substitution in Egypt.

ii In the late 1980s the public sector banks' share of assets was estimated to be around 90 per cent (Roe 1998). The World Bank database on financial structure shows that 60 per cent of assets were held in banks in which the government's shareholding exceeded 50 per cent in 1997.

iii The figure shows a quarterly interpolation of the annual data (using the method of Lisman and Sandee, 1964) that will be used in the econometric model in the next section.

${ }^{\text {iv }}$ By assumption, shocks to the share of money made up by cash are orthogonal to shocks to total money demand.

${ }^{\mathrm{v}}$ The source for $y$ is given in footnote 7. $C$ is taken from IFS and D from the Central Bank of Egypt Quarterly Bulletin.

${ }^{\mathrm{vi}} R$ is the ratio of commercial bank reserve assets reported in IFS to domestic currency bank deposits as reported in the Central Bank of Egypt Quarterly Bulletin; $y$ is a quarterly interpolation of nominal annual GDP as reported in World Development Indicators deflated by the quarterly consumer price index in IFS; $b$ is taken from the World Currency Yearbook; $r$ is taken from IFS.

${ }^{\text {vii }}$ As can be seen in Table 2 below, the lag orders selected are $T_{R}=0, T_{s}=0, T_{b}=3, T_{r}=3$ and $T_{v}=1$.

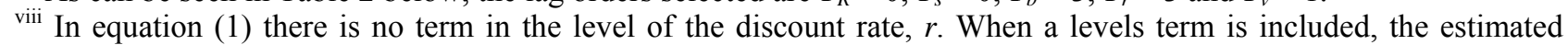
coefficient is very close to zero (and statistically insignificant). Implicitly, changes in the discount rate have only a short-run effect on the reserve ratio.

${ }^{i x}$ There is no ready theoretical explanation for the non-monotonicity of the $\ln (v)$ impulse response profile. The nonmonotonicity arises from the negative coefficient on $\Delta \ln (v)_{t-1}$ in Table 2, which is significant at the 10 per cent level.

${ }^{\mathrm{x}}$ The figure of 0.23 comes from our estimate $\theta / \beta *$ of in equation (1). The figure of 0.08 comes from multiplying our estimate of $\Sigma_{i} \delta_{i} / \beta *$ by the difference between average $\Delta \ln (b)$ in the pre-reform period and average $\Delta \ln (b)$ in he postreform period.

${ }^{x i}$ This figure comes from multiplying the difference between average $\ln (v)$ in the pre-reform period and average $\ln (v)$ in the post-reform period by our estimate of $\eta * / \beta *$.

${ }^{\text {xii }}$ Equilibrium $\ln (R)_{t}$ is calculated as $\left(\beta_{0}+\phi \cdot t+\theta \cdot R E F O R M_{t}+\gamma^{*} \cdot \ln (y)_{t}+\eta^{*} \cdot \ln (v)_{t}\right) / \beta^{*}$, and Figure 7 shows the corresponding level, $R_{t}$. The differences between the actual reserve ratio (Figure 1) and the equilibrium ratio are largely due to the effects of temporary movements in the parallel market exchange rate. The corresponding non-violence equilibrium omits $\eta^{*} \cdot \ln (v)_{t}$ and the non-reform equilibrium omits $\theta \cdot R E F O R M_{t}$. The figures are calculated on the assumption that the parallel market exchange rate and the central bank rediscount rate are constant in the long run. 
Table 1: Regression Equations for $\ln (y)$ and $\ln (C / D)$

$\Delta \ln (\mathbf{C} / \boldsymbol{D})_{t}$ equation (The regression includes a seasonal intercept and trend.)

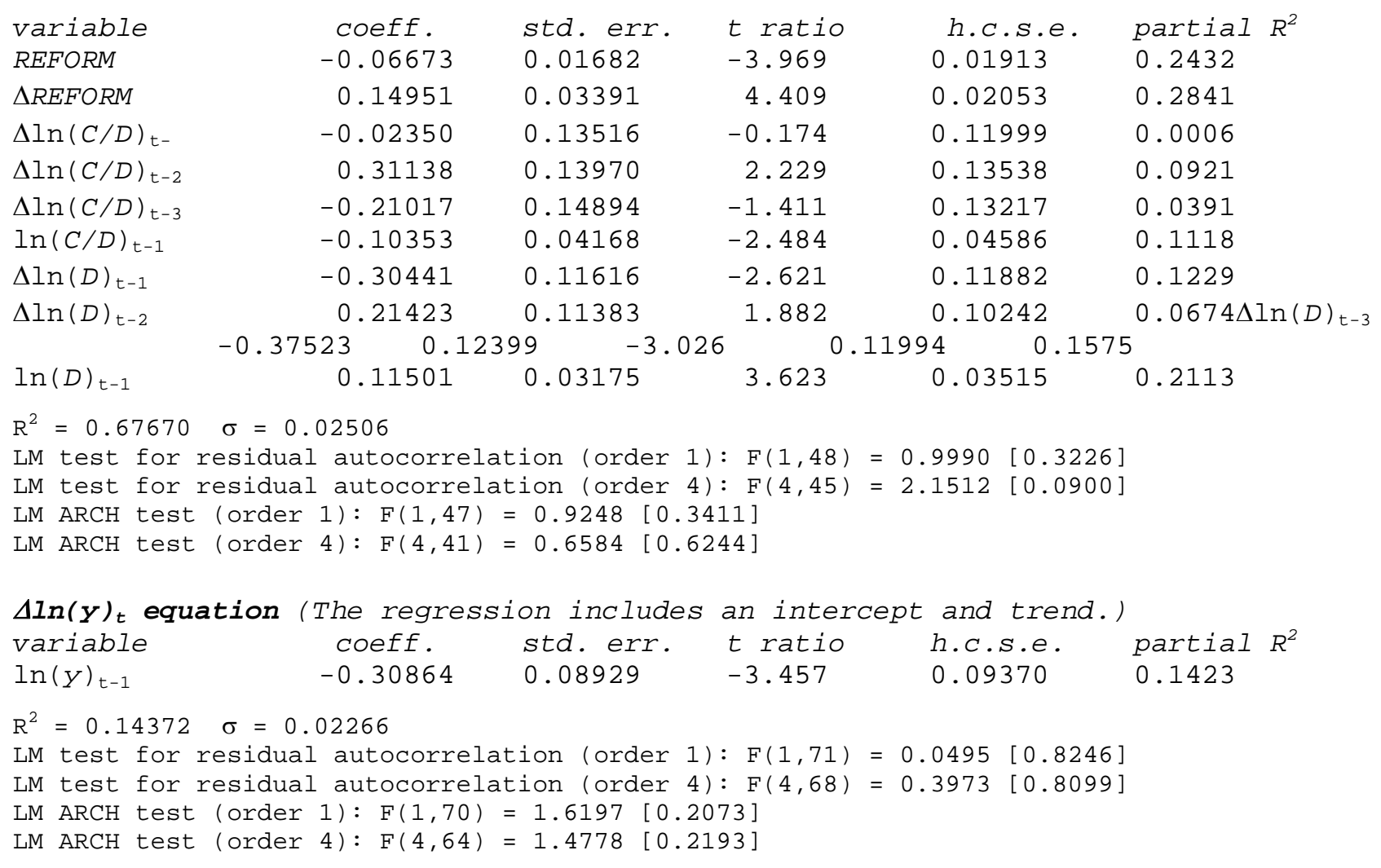

Table 2: Regression Equation for $\Delta \ln (R)_{\mathrm{t}}$

\begin{tabular}{|c|c|c|c|c|c|c|}
\hline $\begin{array}{l}\text { Variable } \\
\text { intercept } \\
\text { trend } \\
\text { REFORM }\end{array}$ & $\begin{array}{l}\text { coeff. } \\
-4.61710 \\
-0.01543 \\
-0.11717\end{array}$ & $\begin{array}{l}\text { std. err. } \\
0.02319 \\
0.00445 \\
0.03621\end{array}$ & $\begin{array}{l}t \text { ratio } \\
-1.991 \\
-3.469 \\
-3.236\end{array}$ & $\begin{array}{l}\text { h.c.s.e. } \\
3.00680 \\
\odot .00608 \\
\odot .02994\end{array}$ & $\begin{array}{l}\text { partial } R^{2} \\
\odot .0945 \\
\odot .2405 \\
\odot .216 \odot\end{array}$ & $\begin{array}{l}\text { ins. } \\
0.04 \\
0.04 \\
0.03\end{array}$ \\
\hline$\Delta r_{\mathrm{t}}$ & 0.05387 & ๑. 01192 & 4.520 & $\odot .00728$ & $\odot .3496$ & 0.06 \\
\hline$\Delta r_{\mathrm{t}-1}$ & ๑. .03359 & $\odot .01210$ & 2.776 & $\odot .009 \odot 4$ & 0.1686 & 0.05 \\
\hline$\Delta r_{\mathrm{t}-2}$ & ๑ . 02925 & ๑. 01169 & 2.503 & $\odot .0 \odot 683$ & $\odot .1415$ & 0.03 \\
\hline$\Delta r_{\mathrm{t}-3}$ & ๑. . 02388 & 0.01147 & 2.082 & $\odot .00966$ & 0.1024 & 0.05 \\
\hline$\Delta \ln (b)_{\mathrm{t}}$ & 0.36554 & $\odot .12715$ & 2.875 & 0.11718 & 0.1786 & 0.03 \\
\hline$\Delta \ln (b)_{\mathrm{t}-1}$ & 0.33868 & 0.14191 & 2.387 & 0.10078 & 0.1304 & 0.08 \\
\hline$\Delta \ln (b)_{\mathrm{t}-2}$ & 0.41241 & $\odot .15556$ & 2.651 & 0.14042 & $\odot .1561$ & 0.07 \\
\hline$\Delta \ln (b)_{\mathrm{t}-3}$ & 0.32774 & ๑.14122 & 2.321 & $\odot .10090$ & 0.1241 & 0.03 \\
\hline$\Delta \ln (v)_{\mathrm{t}}$ & $\odot .14722$ & $\odot .06229$ & 2.364 & $\odot .06822$ & ๑. 1282 & 0.02 \\
\hline$\Delta \ln (v)_{\mathrm{t}-1}$ & $-\odot .09076$ & $\odot .05279$ & -1.719 & 0.05458 & $\odot .0722$ & 0.04 \\
\hline$\Delta \ln (y)_{\mathrm{t}}$ & 0.72055 & 0.44174 & 1.631 & $\odot .56570$ & 0.0654 & 0.06 \\
\hline $\ln (R)_{\mathrm{t}-1}$ & -0.51171 & ๑. 09199 & -5.563 & 0.10770 & 0.4488 & 0.03 \\
\hline $\ln (v)_{t-1}$ & ๑. 06779 & ๑.01884 & 3.597 & 0.02133 & ๑. 2540 & 0.04 \\
\hline $\ln (y)_{t-1}$ & $\odot .84860$ & 0.44303 & 1.915 & 0.57469 & ๑.๑881 & 0.04 \\
\hline
\end{tabular}

h.c.s.e.: heteroskedasticity-corrected s.e. ins: Hansen (1992) parameter stability stat. $\mathrm{R}^{2}=0.66637 \quad \sigma=0.05306$

Hansen (1992) joint parameter instability test statistic $=2.6103$

LM test for residual autocorrelation (order 1): $F(1,37)=1.1366$ [0.2933]

LM test for residual autocorrelation (order 4): $F(4,34)=0.6437[0.6351]$

LM ARCH test (order 1): $F(1,36)=0.7459[0.3935]$

LM ARCH test (order 4): $F(4,27)=1.2098[0.3296]$

Joint significance of levels variables: $F(3,35)=9.8059$ 


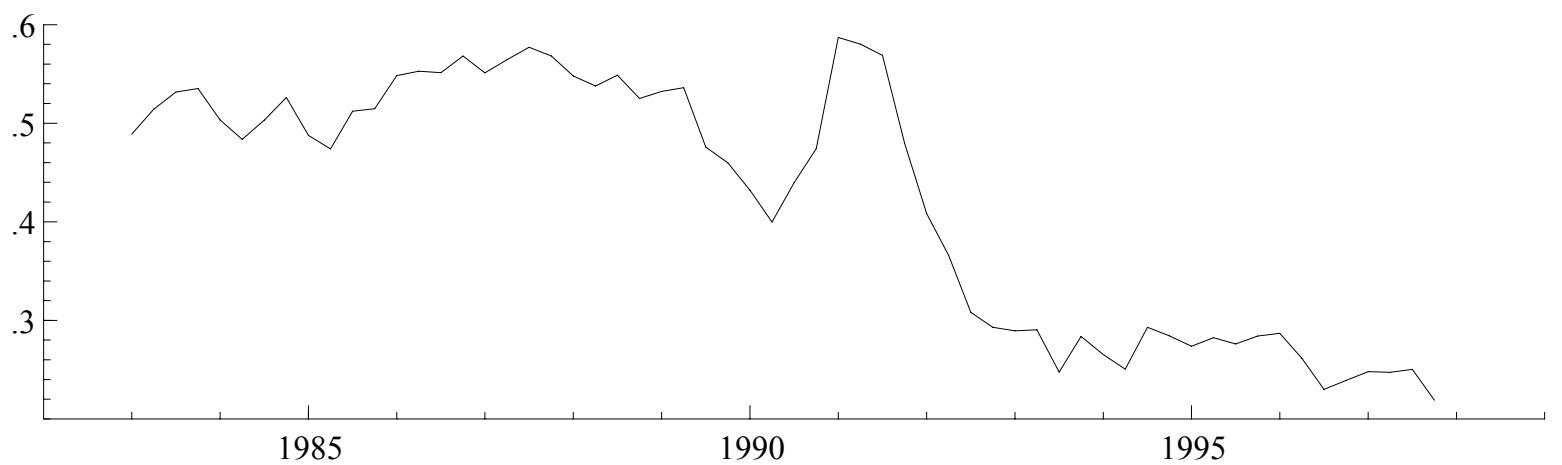

Figure 1: The Ratio of Commercial Banks' Reserve Assets to Domestic Currency Balances

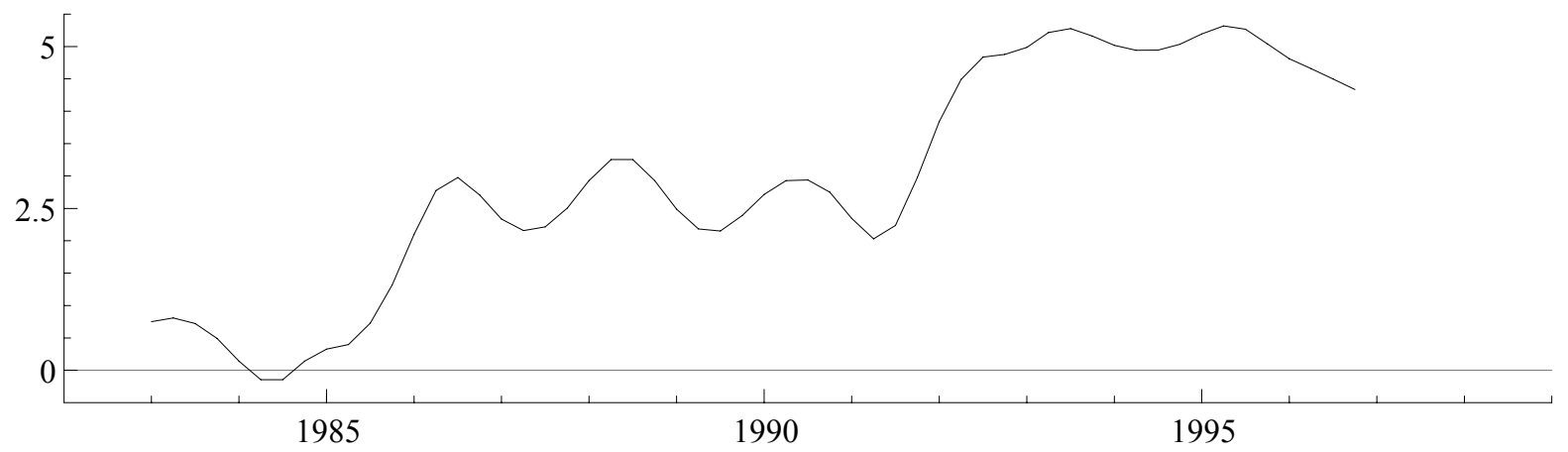

Figure 2: The Log of Annual Violent Political Incidents in Egypt (Quarterly Interpolation)
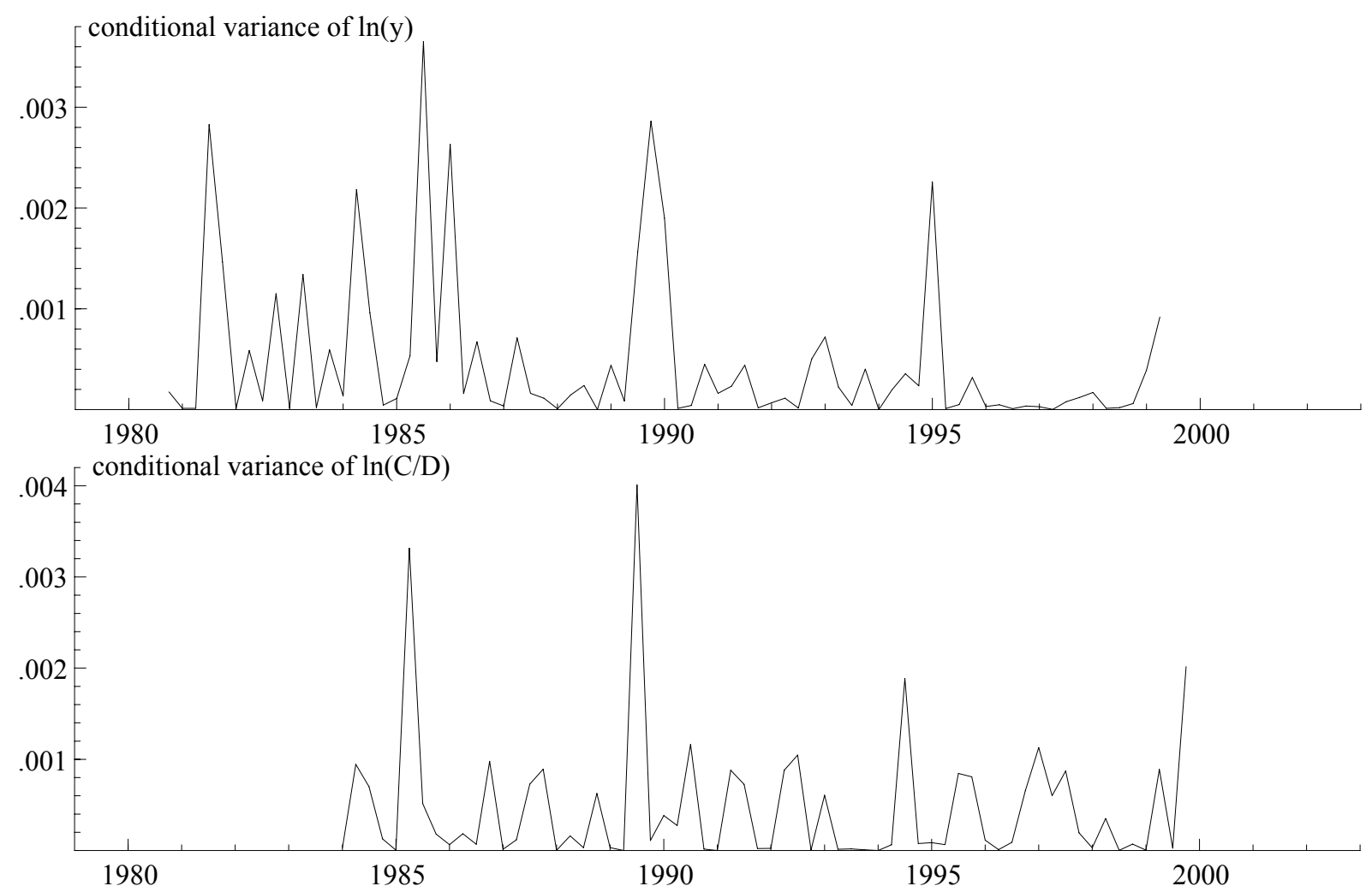

Figure 3: Conditional Variances of $\ln (y)$ and $\ln (C / D)$ 


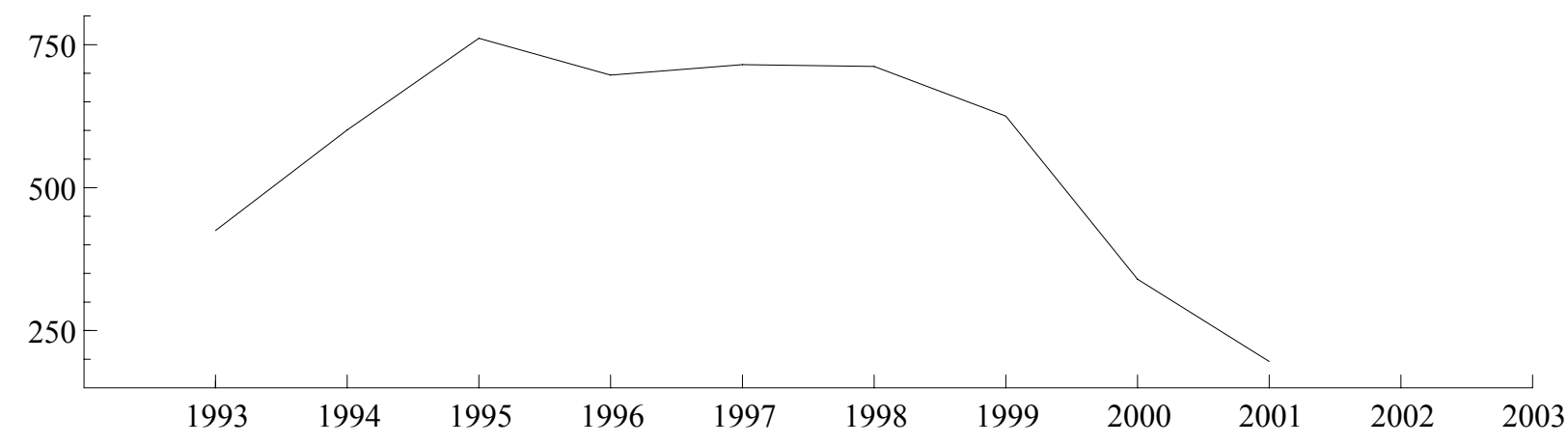

Figure 4: Annual Total Bankruptcies

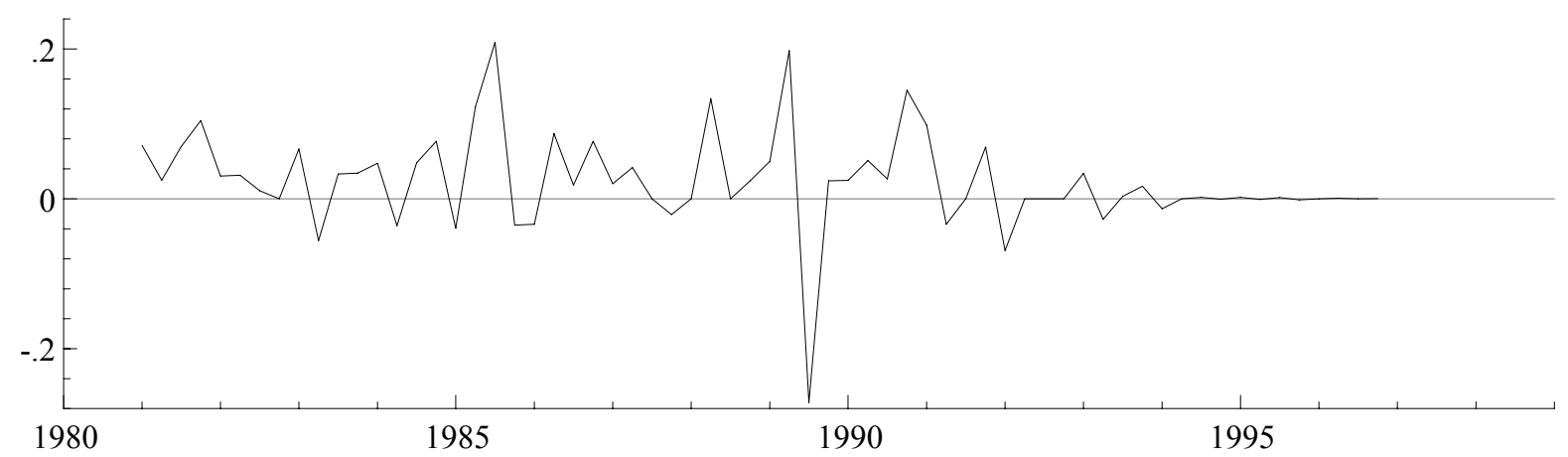

Figure 5: Quarterly Rate of Black Market Exchange Rate Depreciation
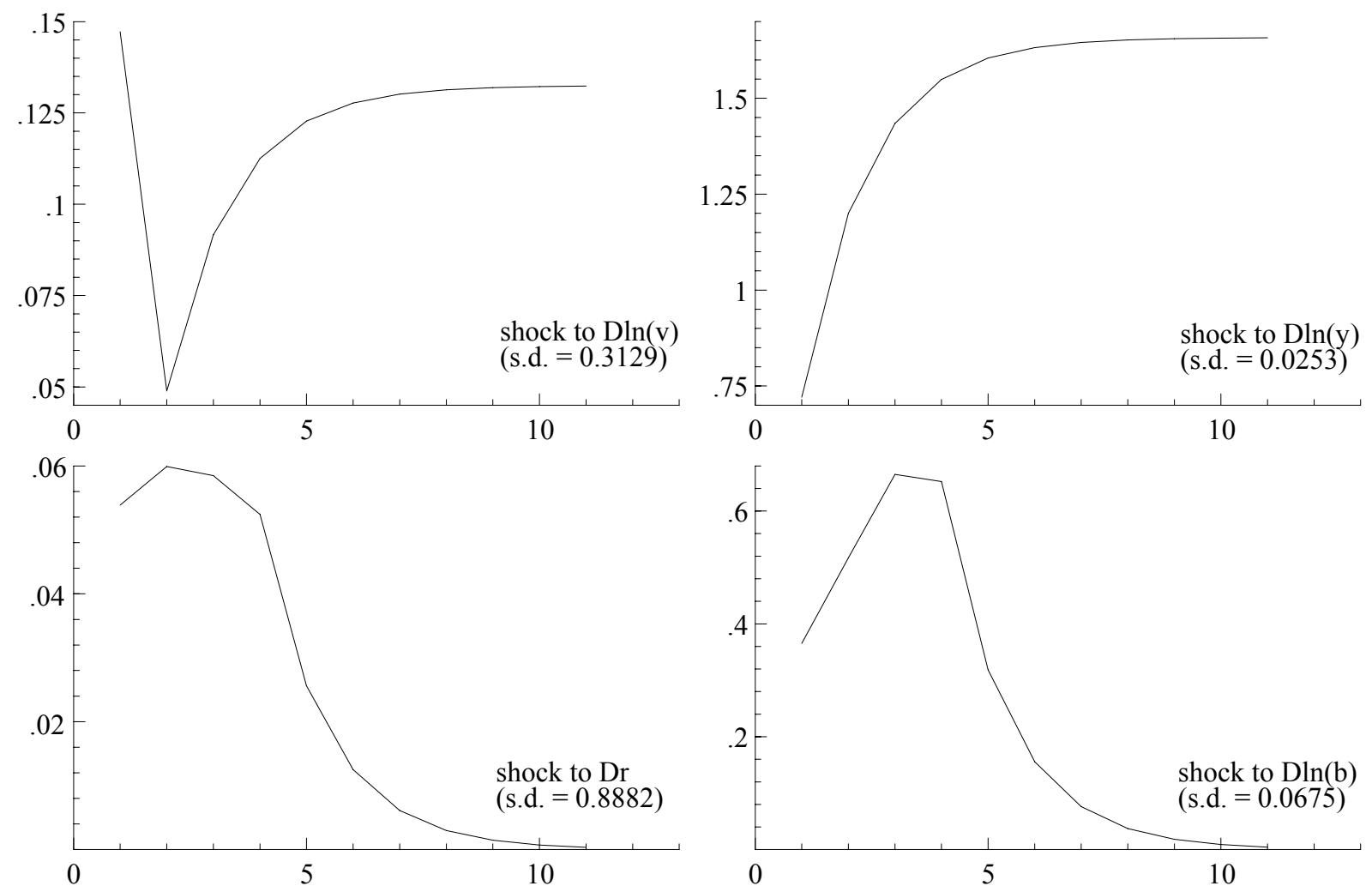

Figure 6: Response of $\ln (R)$ to Unit Shocks to Explanatory Variables, by Quarter Standard Deviations of Variables are Shown in Parenthesis 


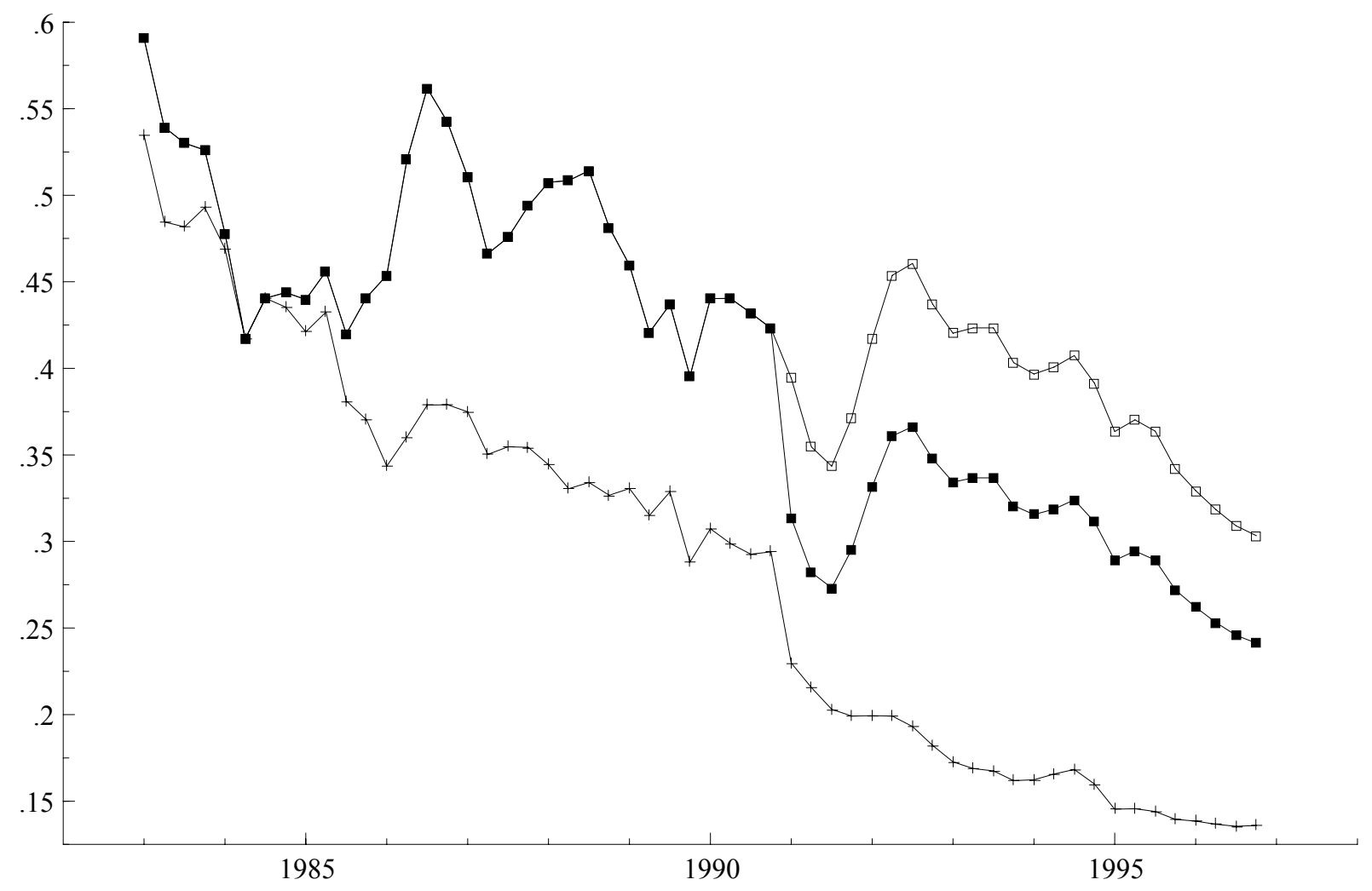

Figure 7: Estimated Equilibrium Reserve Assets Ratio (a) and

(i) Hypothetical Equilibrium Ratio in the Absence of Reform ( $\square$ )

(ii) Hypothetical Equilibrium Ratio in the Absence of Violence (+) 